\title{
RE-ENGINEERING THE POLICE ORGANISATION: IMPLEMENTING WORKFORCE MODERNISATION IN ENGLAND AND WALES
}

\begin{abstract}
This article assesses the need for major re-engineering of the police service in England and Wales to project and sustain the workforce modernisation programme in England and Wales. It argues that having avoided the bureaucratic cul-de-sac that police mergers represented, a real opportunity for effective reform has now arisen. This reform would encompass immediate delegation to basic command units of manpower budgets and the determination of policing services at this level. The article draws on the experience of one chief officer who was to confront the problems of bureaucratic inertia within his own police force and some organisational practices that served to undermine police service delivery. It considers the current problems surrounding the centralised control of police budgets and the impact of this on the ability of BCU Commanders to sustain effective reassurance policing. The article also assesses the impact and future implications of workforce modernisation along with recent evaluations of the PCSO and 'mixedeconomy teams' from pilot sites. Finally the article draws on recent experience from one police force Chief Officer Team to evaluate the continuing problem of police organisational culture particularly in relation to workforce modernisation and the future expansion of the role of police staff within police forces in England and Wales.
\end{abstract}

\section{Introduction}

The 2006 summer announcement by the Home Secretary finally buried the programme of regional police mergers. Instead of mergers the Home Office now wants collaboration between police forces and also the introduction of workforce modernisation (Home Office, 2006). In addition some features of the police organisation need evaluation for possible major re-engineering to improve the efficiency and effectiveness of the police service.

These are: current management structures and the absence of delegated budgets; a need to identify effective spans of control 
within BCUs; and the current police hierarchy, where eight ranks continue to exercise a managerial responsibility over the police constable. Additionally, recent experience in one regional police force suggests the interface between police officers and police staff requires fundamental re-evaluation. This would embrace the police organisational culture along with the lessthan-credible management skills exhibited by a number of senior police managers within the police service.

\section{Sunset over Northallerton}

The clear commitment to the enforced merger plan propounded by Charles Clarke as Home Secretary was to be supported among a small number of chief constables. These were expected, however, to be the beneficiaries of reform by their being appointed to run the new 'super-forces'. One regional force was likely to have been led by the chief constable of North Yorkshire, who was expected to take responsibility for the merger of the three Yorkshire police forces. John Reid, however, was finally not to be persuaded of the value of such amalgamations. This may have reflected only in part an earlier position taken within the Prime Minister's Strategy Unit (PMSU) in 2004 that amalgamation represented the very last option that should be contemplated in terms of improving police efficiency (PMSU, 2004). This policy position may have been resurrected by PMSU with the demise of Charles Clarke, who, with a small number of senior police officers, proved to be a major proponent of the merger programme.

As these plans unfolded it became evident that, while they may have been supported by a small number of chief police officers and HMIC, they did not meet with popular approval. This was to be highlighted by way of elaborate public consultation exercises undertaken by a number of police forces and police authorities. These included wide public consultation meetings conducted by Cleveland and West Mercia police authorities. It appeared that the police reform merger plan was very largely 'producer-driven' rather than 'consumer-led', which served to contradict the Prime Minister's own aims for public services reform (Cabinet Office, 2003). Nor was it clear how much the total cost of police mergers might prove to be. As no evidence was to be cited within HMIC's Report Closing the Gap and no evaluation of the costs of previous amalgamations was to be provided either, there was a justified fear that costs could prove to be very substantial (Brain, 2006). 
Subsequently it was to be reported that the chief officer and police authority of Cumbria was to ask for and receive an apology from the Prime Minister in connection with the proposed merger of Cumbria and Lancashire constabularies and the decision not to go forward with it. Yet, as was to be noted, the merger had been decided between the chief constables of the respective police forces, who aimed to push this through in the absence of any support for this largely unwanted development among the local public.

The Prime Minister's formal apology ignored the fact that the community had demonstrated strong opposition to the merger. This had been manifested by way of popular petitions opposing amalgamation organised locally by members of parliament (Gilbert, 2006). It might, ironically, have been more appropriate if the apology from the Prime Minister had been more immediately directed to the residents of Cumbria. These came very close to experiencing the worst excesses of professional control of a public service in the determination of its structure and thereafter the level and standard of service delivery.

\section{Managing Reform in the Police Service}

The remote and centralised bureaucracies that the planned 12 regional forces would have created actually would have resulted in the appearance rather than the reality of reform. The lengthy bureaucratic exercise initiated by amalgamation also would have served to ensure that real public service reform could be sidelined. Priorities of chief officers and senior managers would inevitably have been directed to police force reorganisation even though the benefits of this had never been clearly established (Loveday, 2006).

The need for reform remains clear yet this relates very largely to the internal management structure within the police service. This would specifically embrace the management of BCUs and the need to identify effective spans of control within it. To date there has been no independent analysis of what constitutes a viable BCU size and this has been reflected in the way the size of these units have, rather like police forces, grown in terms of police establishments over the last decade.

As originally predicted, the viable size of the BCU was around 250 police establishments but this quickly expanded to 400 (O'Byrne, 2001). In the absence of any objective assessment some BCUs now have establishments of over 1,000 police officers, which effectively undermines the management rationale 
identified as the basis for their creation (O'Byrne, 2001). As originally argued, the BCU with 250 officers provided a span of control that effectively could be exercised by one senior officer. Additionally, the BCU also provided a flatter unit for police delivery, which helped reduce the traditional police hierarchy.

The growth in size of the BCU has, in many police forces, served to undermine the earlier rationale for these units. Moreover, as they have grown in size the need for an extended police hierarchy has also been re-established. Additionally, the aim to delegate managerial responsibility to BCU commanders has also been confounded as the majority of these officers do not have effective control over the budget and have no immediate responsibility for police manpower. To some degree this problem has been compounded by the government's commitment to keeping up police force establishment by way of the Crime Fighting Fund (CFF).

Yet the reality within many police forces continues to be that central police headquarters is not prepared to address effective delegation as this could raise major questions about its own future role. Public service reform remains, however, committed to delegating financial responsibility down to those closest to consumers of the service (Cabinet Office, 2003: 3). As in many other public services, police service manpower spending accounts for approximately $80 \%$ of all spending and is the single most critical spending area for operational police managers. But, as a survey conducted for the Police Superintendents' Association in 2003 was to discover, for most BCU Commanders the only immediate areas of responsibility not requiring referral to Police HQ proved to be 'office equipment' and 'overtime payment' (Police Superintendents' Association, 2003).

In the absence of effective delegation of manpower budgets to BCUs there may, ironically, be less commitment to the encouragement and implementation of police reform. This may be particularly the case in relation to the further use of police staff and the extended 'police family'. Evidence suggests that BCU Commanders acting independently would be prepared to embark far more on the wider recruitment of police staff than on that of police officers. They are aware that the wider use of police staff currently offers much greater value for money than the simple increase in police establishment (Loveday \& Reid, 2003). This assessment would, of course, provide a useful spring-board for the greater implementation of the workforce modernisation programme currently being piloted in a number of police force areas. 
Yet there is much to recommend the internal management reform identified within the BCU structure. Delegated budgets and freedom given to commanders to use those budgets could provide the most effective method of improving police service in the $\mathrm{BCU}$ area. It might also provide the trigger for important changes in local delivery of service. To date, however, very little has been achieved in either arena. This is not unconnected to a degree of suspicion and opposition to it among both chief officers and HMIC (HMIC, 1998: 2).

This opposition is reflected in the demand for 'corporacy' expressed currently by many chief officers. In effect 'corporacy' places great importance on centralised management that has been the traditional characteristic of police forces. It has at the same time, however, been a characteristic that has sustained extended police hierarchies now seen as a marked impediment to effective service delivery.

\section{Police Management and Service Delivery}

Delegation down to BCU level in addition to reducing police hierarchies may also go some way to provide an opportunity for challenging workforce practices that blight the delivery of police services. Although no detailed evaluation of these practices can be attempted here, it is accepted that there is a need for a significant review of these issues. While most police forces have been encouraged to act on these practices, the problems associated with ill-health, injury, early retirements, shift patterns and police allowances remain the subject of continuing concern.

Although a number of chief constables have taken up the challenge, the experience of the (then) chief constable of West Yorkshire proved to be instructive. He related how he had confronted a system where it was accepted that officers might seek early retirement on quite spurious grounds but it was accepted as entirely legitimate because it was seen as 'part of the system' (Hellawell, 2002: 246-7). He noted, however, that:

There was a twist to the ill-health scenario. If an officer could prove he was retiring as the result of injury on duty he received an enhanced pension in the form of a lump sum and annual payments of several thousand pounds for the rest of his life, all of which was tax-free. More and more officers were taking advantage of this rule and compared with others my force had the largest percentages of officers receiving enhanced payments. (Hellawell, 2002: 246) 
The same chief officer also investigated officers who had retired on ill-health grounds. He discovered a range of abuses where officers with attractive pensions were working in a variety of capacities from which their claim of ill-health should in theory have precluded them. Analysing a number of ill-health retirements, this officer argued that there were in fact many claims that appeared to be entirely spurious (Hellawell, 2002: 248). Interestingly, while this chief officer quickly recognised the real costs of these claims, many of his fellow officers did not share his concern. As he stated about his ACPO colleagues:

I shared my force's ill-health record and the methods I adopted to deal with it with my fellow chief constables, who were not particularly interested as it was not a big issue for them and took no remedial action. The result is that in the past decade police sickness and ill-health retirements have spiralled out of control becoming a major drain on finances. (Hellawell, 2002: 249)

Nor did the problem concern only early retirements. It also became apparent that many working practices had over the years been introduced not on the basis of need but in effect to 'keep the workforce happy' (ibid.). One example cited by the same chief officer concerned a police officer's 'place of duty'. Here, if an officer had to work anywhere else on a temporary basis they would be automatically entitled to compensation for both travel and meals. Yet if the officer worked at the new location for more than 60 days the benefit ceased. This chief officer was to discover that this not surprisingly explained the large number of 'peripatetic squads' who, he argued, abused this regulation systematically:

Peripatetic squads claimed - every day they worked wherever they were. Their supervisors would arrange for them to spend the sixty-first day in a different location so that the sixty-day clock might start to run again and they could go on drawing benefit. Officers could claim reimbursement for travel even if their temporary places of duty were closer to their home than their normal station. (Hellawell, 2002: 250)

Further issues confronted by this officer included 'overmanning' problems. In nearly every incident investigated 'at least 3 and usually 4 officers were involved each from a different 
department and with little coordination between them' (Hellawell, 2002: 251). The process could also be very timeconsuming. As a result, victims effectively waited on the police who controlled the nature and timing of their response rather than the police service responding to them.

While CID were to claim that they were under-resourced, internal investigation highlighted how in West Yorkshire specialist departments operated as closed shops and certain departments (particularly CID) were disproportionately funded bcause $80 \%$ of the force overtime budget went to the detectives constituting only $13 \%$ of the full establishment (Hellawell, 2002: 252). It was also discovered that the CID had excessive overheads in terms of supervisory staff vehicles and buildings.

Within this CID department one sergeant supervised three constables and one inspector supervised two sergeants. They also had one quarter of all superintending ranks. In the uniform division the ratios were far higher (Hellawell, 2002: 253). The decision to deal with these anomalies came for this chief constable at great personal cost. He was publicly harangued by intoxicated CID officers at a Federation Meeting held in central Leeds. His family home was subjected to nuisance calls, attempted burglaries and finally extensive criminal damage (Hellawell, 2002: 255). Despite CID opposition, the reforms pursued by the chief officer reflected the fact that uniformed officers had carried the burden of police service delivery. In effect they:

Carried all the vacancies and as a consequence of being under-manned suffered the highest rate of injury and assault on duty, since it was they who had to deal with violent incidents. They carried the highest crime load; they were under the most pressure and they made the most arrests and conducted most interviews. They had to deal with the broadest range of issues as they were the first on the scene whether it be a murder, a road accident or a pub fight. They were the lowest paid and the least experienced as quite understandably everyone worked to escape from the position of uniformed constable. (Hellawell, 2002: 260)

A further problem relating to that of police hierarchy also was to be highlighted by this officer. This concerned the internal organisational pressure to create more senior posts that inevitably came at the expense of front-line officers. Their numbers were to be eroded by increases in supervisory staff. The result of upward pressure on senior posts proved to be startling. 
If you visit any police station in this country during the day you will find almost as many people of rank on duty as constables out on the streets. What would your reaction be if that were so in schools or hospitals? (Hellawell, 2002: 364)

\section{Need for Local Management of the Workforce}

The workforce problems identified within one police force could well be equally applicable to others. Yet if the application of 'tenure' has radically altered the composition of the CID and eroded the supervisory advantages previously experienced within this department, many problems remain. This may continue to pertain while the extended police hierarchy operates and where delegation of manpower budgets to local commanders is effectively impeded by police headquarters. Yet only by delegating budgets are internal workforce problems likely to be effectively challenged. This is because locally controlled budgets work to expose and highlight wasteful or unjustifiable spending patterns and service costs that are less apparent at the top of the organisation because specific spending patterns can be hidden within the overall police budget.

Where local commanders are responsible for service and spending there may well be pressure to achieve 'value for money'. This would not sit very easily at a local level alongside spurious claims for ill-health or injury retirements. Where budgets are devolved, local commanders can be expected to make precise judgements about these issues. They are unlikely to support working practices that erode and impact on their own budgets.

The need for effective management delegation particularly in relation to Human Resources (HR) management was identified in West Yorkshire, where the decision was made early on to explore the opportunities of giving local commanders immediate responsibility for local budgets. Prior to this, all decisions in West Yorkshire had been made at headquarters at ACPO rank:

Before my arrival all decisions were to be made in headquarters. The territorial commanders had no control of their budgets, the number or nature of their staff, buildings, vehicles or equipment (even replacement of a pair of gloves had to be authorised by an assistant Chief Officer). Consequently territorial commanders didn't really manage and had limited means of manoeuvre within the constraints laid down at the top. (Hellawell, 2002: 256) 
In order to provide a stronger management base at local $\mathrm{BCU}$ level the decision was taken to devolve responsibility for all spending to this level. Headquarters staff were given a generalised responsibility for setting and monitoring force efficiency and effectiveness. A 'simple but fundamental decision' to devolve virtually all budgets onto operational commanders 'met with their near universal support'. This meant that these officers were made responsible for multimillion-pound budgets. 'Those in headquarters who had hitherto controlled the supply of money and resources were against the proposal because it lessened their power and influence' (Hellawell, 2002: 257). A further review at headquarters was initiated to identify those officers who provided a direct service to the public or who required police powers or police training to do their job. For officers who filled none of these criteria their posts were to be civilianised while they were returned to operational duties. Overall these reforms were to contribute significantly to reducing police force overheads while increasing the number of officers on the streets (ibid.).

Lessons learned from this police force were not, however, picked up by other chief officers, either then or later. Evidence of this is the way police headquarters continues to retain immediate responsibility for police budgets and police manpower.

\section{Non-Delegation of Police Budgets}

The apparent failure of chief officers either to learn from or implement the lessons arising from the West Yorkshire example were highlighted in a survey of all BCU commanders conducted for the Police Superintendents' Association in 2003. This survey asked commanders inter alia to provide details of budgetary decisions they could make unilaterally and those that had to be made either in conjunction with police $\mathrm{HQ}$ or only by police $\mathrm{HQ}$. The results, shown in Figure 1, exposed a startling insight into the unreformed nature of current police financial management and the largely negative impact of the extended police hierarchy at that time.

The single most important budget item, that of manpower, is not delegated to BCU commanders in most instances. Yet these officers are in the best position to make a judgement as to the most efficient and effective manpower profile for the BCU area. Ironically, as earlier identified by Bayley (1994) in relation to many American police departments, delegated financial responsibility rarely goes beyond that of minor expenditure on office 
Table 1 What decisions BCU Commanders can make without reference to Force HQ and what control they have over the budget

\begin{tabular}{|c|c|c|c|c|}
\hline $\begin{array}{l}\text { Base: All } \\
\text { respondents (223) }\end{array}$ & $\begin{array}{l}\text { Respons- } \\
\text { ibility } \\
(\%)\end{array}$ & $\begin{array}{l}\text { Full } \\
\text { control of } \\
\text { budget } \\
(\%)\end{array}$ & $\begin{array}{l}\text { Partial } \\
\text { control of } \\
\text { budget } \\
(\%)\end{array}$ & $\begin{array}{l}\text { No } \\
\text { control } \\
\text { (\%) }\end{array}$ \\
\hline $\begin{array}{l}\text { Office equipment } \\
\text { Operations }\end{array}$ & 87 & 80 & 18 & 2 \\
\hline support & 38 & 23 & 37 & 40 \\
\hline Vehicle fleet & 27 & 21 & 49 & 30 \\
\hline Crime support & 21 & 16 & 34 & 50 \\
\hline Management info & 42 & 20 & 37 & 43 \\
\hline IT & 22 & 14 & 58 & 27 \\
\hline $\begin{array}{l}\text { Property } \\
\text { management }\end{array}$ & 22 & 10 & 61 & 29 \\
\hline Human resources & 32 & 22 & 43 & 35 \\
\hline Police pay & 13 & 32 & 24 & 43 \\
\hline Training & 29 & 14 & 57 & 29 \\
\hline Overtime budget & 77 & 79 & 20 & 1 \\
\hline $\begin{array}{l}\text { Officer staffing } \\
\text { levels } \\
\text { Civilian staffing }\end{array}$ & 37 & 26 & 36 & 38 \\
\hline levels & 42 & 38 & 34 & 29 \\
\hline Maintenance & 52 & 32 & 52 & 15 \\
\hline $\begin{array}{l}\text { Allowances, e.g. } \\
\text { vehicle and } \\
\text { telephone } \\
\text { Income } \\
\text { generation, e.g. } \\
\text { selling police time } \\
\text { to football } \\
\text { grounds }\end{array}$ & 50 & 14 & 58 & 27 \\
\hline
\end{tabular}

Source: Police Superintendents' Association (2003).

furniture, while the big spending is tightly controlled at headquarters (Police Superintendents' Association, 2003).

When the strait-jacket of the Crime Fighting Fund, which places primacy on the employment of police officers over police staff, is added to this extremely circumscribed financial role it becomes immediately clear that BCU commanders effectively 
command little at all. They remain almost wholly driven by and dependent on centralised management direction and decision making based at police HQ level.

Thus the BCU commander's role provides in effect the appearance rather than the reality of delegated command. The evidence for this can be found in the responses of BCU commanders when asked what responsibilities they would like to see delegated (see Table 2 below). The application of central performance targets by government has also acted as a brake on the limited discretion exercised by BCU commanders, as targets have tended to reinforce the traditional top-down command and control approach. This has seen the resurrection of the central

Table 2 Whether commanders would like less, the same, or more control over budgets

\begin{tabular}{|c|c|c|c|c|}
\hline $\begin{array}{l}\text { Base: All } \\
\text { respondents (223) }\end{array}$ & $\begin{array}{l}\text { Less } \\
\text { control } \\
(\%)\end{array}$ & $\begin{array}{l}\text { The same } \\
\text { level of } \\
\text { control } \\
(\%)\end{array}$ & $\begin{array}{l}\text { More } \\
\text { control } \\
(\%)\end{array}$ & $\begin{array}{l}\text { Not } \\
\text { stated } \\
(\%)\end{array}$ \\
\hline $\begin{array}{l}\text { Office equipment } \\
\text { Operations }\end{array}$ & - & 66 & 22 & 12 \\
\hline support & - & 39 & 44 & 16 \\
\hline Vehicle fleet & 1 & 30 & 59 & 10 \\
\hline Crime support & - & 34 & 50 & 17 \\
\hline Management info & - & 43 & 38 & 18 \\
\hline IT & - & 43 & 42 & 14 \\
\hline $\begin{array}{l}\text { Property } \\
\text { management }\end{array}$ & 2 & 43 & 42 & 13 \\
\hline Human resources & 1 & 27 & 61 & 11 \\
\hline Police pay & 1 & 39 & 46 & 14 \\
\hline Training & 1 & 34 & 52 & 13 \\
\hline $\begin{array}{l}\text { Overtime budget } \\
\text { Officer staffing }\end{array}$ & - & 63 & 26 & 11 \\
\hline $\begin{array}{l}\text { levels } \\
\text { Civilian staffing }\end{array}$ & 1 & 26 & 62 & 10 \\
\hline levels & 1 & 34 & 55 & 10 \\
\hline Maintenance & 2 & 46 & 38 & 14 \\
\hline $\begin{array}{l}\text { Allowances, e.g. } \\
\text { vehicle and } \\
\text { telephone }\end{array}$ & 1 & 58 & 25 & 16 \\
\hline
\end{tabular}

Source: Police Superintendents' Association (2003). 
features that characterised the classical school of police organisational management (Souryal, 1995: 485). A consequence of this revival of the classical management approach has been pressure towards the narrowing of spans of control and an extension of the police hierarchy. This is reflected in the ever-increasing size of BCUs, which has required a strengthening of the police hierarchy to manage these enlarged units of policing (Loveday, forthcoming a).

\section{Police Manpower Availability at BCU level}

In spite of the creation of BCUs and their responsibility for the policing of their areas it is evident that Police HQs still determine budgets and have influence, if not total control, over the operational functions of the BCU. This is manifested in a number of ways.

Perhaps the most significant of these, given the importance of visible policing, is manpower availability at BCU level. Once again a survey of BCU commanders revealed the limited power given to local commanders over what continues to be the primary resource at this level. In the analysis of the abstraction rate (a highly significant element of manpower availability) it was discovered that in many BCUs the total number of officers available for duty could be eroded by the impact of abstractions (see Table 3 below). The abstraction rate reflects the sickness and training withdrawals over which the BCU commander has little influence. This may also extend to the matter of vacant posts and is significant, particularly if these vacancies are heavily loaded towards the beat constable. This problem within the police organisation has been identified by police managers and others over many years and reflects a continuing bias towards the

Table 3 Overall abstraction in BCUs

\begin{tabular}{ll}
\hline Base: All respondents (223) & $\begin{array}{l}\text { Proportion falling } \\
\text { into band } \\
(\%)\end{array}$ \\
Abstraction rate & 12 \\
\hline $0-10 \%$ & 31 \\
$11-20 \%$ & 9 \\
$21-25 \%$ & 17 \\
$26-30 \%$ & 15 \\
$31-40 \%$ & 10 \\
$41 \%+$ &
\end{tabular}


Table 4 Overall abstraction in BCUs due to sickness, training and vacant posts

\begin{tabular}{ll}
\hline Base: All respondents (223) & $\begin{array}{l}\text { Proportion falling } \\
\text { into band } \\
(\%)\end{array}$ \\
Abstraction rate & 12 \\
\hline $0-7 \%$ & 46 \\
$8-15 \%$ & 17 \\
$16-20 \%$ & 8 \\
$21-25 \%$ & 4 \\
$26-30 \%$ & 5 \\
$31 \%+$ & 5
\end{tabular}

provision of specialised squads at the expense of visible patrol work (Mervyn Jones, 1980; Loveday, 1999; Hellawell, 2002). The issue of vacancies, when taken alongside that of sickness and training, can reduce availability of staff significantly, as shown in Table 4 below. Within the same survey BCU commanders were asked to identify abstraction rates that were a direct result of Police HQ requirements. This demonstrated that a very high proportion of BCUs $(81 \%)$ could expect to lose between $5 \%$ and $10 \%$ of manpower as a consequence of Police HQ demands (see Table 5 below).

Interestingly, commanders within the same survey who reported that they had received either 'not much' or 'no support' from the chief officer team experienced a much higher than average level of abstractions due to HQ requirements than those who reported that they did receive support. While these data may be, to a degree, subjective and should be treated with some

Table 5 Overall abstraction in BCUs due to HQ requirements

\begin{tabular}{ll}
\hline Base: All respondents (223) & $\begin{array}{l}\text { Proportion falling } \\
\text { into band } \\
(\%)\end{array}$ \\
Abstraction rate & 61 \\
$0-5 \%$ & 20 \\
$6-10 \%$ & 6 \\
$11-15 \%$ & 2 \\
$16-20 \%$ & 2 \\
$21 \%+$ & 2 \\
\hline
\end{tabular}

Source: Police Superintendents' Association (2003). 
caution, it still provides further evidence of the lack of control exercised by local commanders at an operational level over police availability and police patrol presence on the streets. When these data are added to that of non-delegation of budgets the reality of current BCU structures becomes immediately apparent. While they may be identified as BCU commanders, currently these officers effectively command very little at all.

\section{Police Staff and Workforce Modernisation}

In the event of police budgets being effectively delegated down to the BCU there is clear evidence that BCU commanders would prefer to make much greater use of police staff than increase police establishment (Police Superintendents' Association, 2003). Investing in civilian police staff is likely to provide much greater flexibility in management terms than the employment of yet more police officers.

This trend towards greater use of police staff has been encouraged by the increased recruitment of Community Support Officers (PCSOs) and can be expected to expand yet further following on from workforce modernisation policies currently being piloted in a number of police forces. While the results have yet to be fully evaluated, the evidence to date suggests that the future implementation and use of 'mixed economy police teams' is likely to prove highly beneficial in terms of both crime investigation and public reassurance policing (Loveday, forthcoming $b$ ). The expected role and function of mixed-economy teams when linked to the expansion to around 24,000 Community Support Officers provides evidence of the nature and extent of police reform and how this could, if fully implemented, fundamentally alter the policing landscape in England and Wales.

Evidence of the initial results arising from the pilot-sites has already been publicised (Police Professional, 2006). This suggests that with the use of mixed-economy teams the number of detections has increased and the time taken to deal with them has fallen significantly. A similar result has arisen in relation to fear of crime among the public, where survey data indicate that visible policing led by mixed-economy teams has also significantly reduced what had proved previously to be a challenging problem to police forces.

In the Metropolitan Police Service the Bexley pilot has demonstrated similar gains from the expanded use of police staff. In Bexley, for example, the use of police staff in the role of Investigative Support-Officers (ISOs) has proved to be highly 
effective. The first significant change followed an internal evaluation of the investigation and management of crime. A decision was made to end the system where individual CID officers were made fully responsible for investigating individual cases 'from cradle to grave' and were also responsible for setting up ID parades and collecting witness statements etc. (Metropolitan Police Service, 2006).

The use of ISOs has meant that in relation to volume crime (which remains a central government target) many cases can be dealt with in much shorter time. To date no evaluation has been undertaken of how the time freed up by the use of ISOs has been used by CID officers. An initial assessment indicates, however, that much more crime within the Borough has been 'screened in' and that many more initial leads in an investigation have been followed up. One result was that while recorded crime was going up the crime clearance rate was also rising (Metropolitan Police Service, 2006).

Further evidence from the Bexley pilot site was to highlight how the use of police staff to respond to non- emergency calls had proved of value. An initial analysis of calls made to Bexley OCU (Operational Command Unit) revealed nearly a third of all such calls did not require a police response at all. Where PCSOs responded to these calls they had in effect 'professionalised the mundane' by dealing with service calls that very often the police did not want to deal with (Metropolitan Police Service, 2006). The use of PCSOs had been (after Ministerial confirmation) extended to local (and high-profile) Police Response Teams where police officers supported their inclusion. Interestingly, analysis of calls for assistance revealed that police were 19 times more likely to call for PCSOs than PCSOs were to call for police support (ibid.).

\section{Recent Research on the PCSO role}

Evidence from the workforce modernisation pilot sites suggests that mixed-economy teams have much to offer. Elsewhere recent empirical research conducted within one force area on Police Community Support Officers has concluded that, far from being 'plastic policemen' as claimed by the Police Federation, the PCSO has proved to be pioneering (Tazzini, 2006). Evidence from Essex Police suggests that the 600 PCSOs now employed by the police force are demonstrating the intrinsic value of visible patrol by the way they are 'forging lasting personal relationships with stakeholders in their communities and are 
beginning to enhance the social fabric of the communities they serve' (Tazzini, 2006).

The same research found that, in addition to enjoying closer links with the community, the PCSO can be expected to spend on average $49 \%$ of their time on visible patrol, which compares very favourably with that of police officers who on average spend just $15 \%$ of their time on visible patrol and dealing with incidents. Additionally, where there has been evident resistance within the police service to the introduction and expansion of Community Support Officers their arrival has, however, challenged previously held assumptions about the role of the police officer. Claims that PCSOs were merely plastic police 'decries the significant reassurance benefit that they undoubtedly provide to communities' where PCSOs were found already to provide a 'crucial tool to tackle low level crime, nuisance and disorder that blight many communities' (Tazzini, 2006: 29). The introduction of PCSOs is seen to fit within the government's workforce modernisation agenda in that:

Our mindset has previously meant that only police officers can do policing or community safety. PCSOs alert to signals and signal crimes in their area have changed this. It has challenged the monopoly that sworn officers with their pay terms and conditions have enjoyed for many core police roles. (Tazzini, 2006: 27)

There are, however, perceived to be continuing challenges surrounding the roll-out and use of PCSOs. One challenge relates to the need to provide effective supervision of these officers. This could be problematic if police officers slowly withdraw from patrol activity leaving this function entirely to PCSOs. A further challenge arises from the police organisational culture, which will need to change for PCSOs to provide an effective service. This is seen as providing the biggest challenge to both the PCSO programme and the overall Police Reform Agenda. As is noted, however:

Like other professions such as teaching we are using assistants and some are against this. The rank structure of the police officer has been set for many years and policing has been the monopoly reserve of the police officer. Overnight we have brought in an addition with PCSOs and some see this as a threat. (Tazzini, 2006: 27) 


\section{Police Organisational Culture and Workforce Modernisation}

The police culture has been the subject of considerable comment and research over recent years (Reiner, 2000; Chan, 1997). However, the relationship between civilian staff and police officers has been one that from its inception has presented acute management challenges for both civilian and police managers (Howgrave-Graham, 1947). The role and status of civilian staff has been the subject of ongoing debate within the police service, which has traditionally been highly protective of its own.

The protection of civilian employee interests has also proved to be of only limited concern to police managers. These employees have often had to depend on the police authority to provide some, albeit limited, defence of their interests. The Police Acts of 1994 and 1996 effectively ended this protection when the chief constable became the budget holder and primary employer of police staff. How effective the chief officers team (COT) has proved to be in providing support to civilian staff has varied among police forces. There is evidence to suggest that an underlying resistance to the employment of civilian staff has been a central thread running through the police culture and has permeated the police service over many years (HMIC, 2004: Appendix J, 71).

The number of civilian staff now accounts for approximately $35 \%-40 \%$ of the overall payroll within all police forces. Since the rapid expansion of civilianisation started in the 1980s many of the functions that have been civilianised are identified as crucial to the effective delivery of the service. Yet this to date has never been adequately reflected in either the status or pay rates accorded to these officers. Indeed, in terms of professional training, career development pay-scales and pension arrangements, civilian staff have been seen (and see themselves) as ‘second-class employees' (HMIC, 2004: Appendix J, 70).

It is within this context that the planned major expansion of PCSOs and the move to mixed-economy teams within the modernisation process has to be viewed. The perception remains that for the most effective use of PCSOs there had to be a 'change in the police culture'. This means that:

PCSO's raison d'etre must be engrained within the psyche of each Neighbourhood Policing Team and the whole (police) organisation. Influencing such change requires changing the paradigms that comprise the police culture. (Tazzini, 2006: 27) 
It has proved extremely difficult to effect change within the police culture, which has remained remarkably resilient and also resistant to reform. This has, of course, been cemented by the degree to which the Police Federation and other associations have been able to protect police officer interests when confronted with reform. This was demonstrated in 1993 when the major recommendations of the Sheehy Report were very publicly rejected (Loveday, 1998; forthcoming b).

Breaking into and breaking down the police organisational culture is proving to be one of the greatest challenges facing Workforce Modernisation. This is made more difficult by the stance taken to this process by the Police Federation. It remains a strong opponent of what it describes as 'policing on the cheap'. It is also highly critical of a programme that it views as a direct threat to the status and role of its members. These perceptions are not, however, confined to Police Federation representatives. They may in fact permeate the whole organisation up to and including chief officer teams. This element of the police culture has been most recently evidenced in the Devon and Cornwall Constabulary's senior command team. Here a major management initiative, directed at civilian staff, was pursued by the command team with what proved to be quite disastrous consequences.

\section{Meltdown at Middlemoor}

In what proved to be a remarkable case of managerial misjudgement, the Chief Constable of Devon and Cornwall Constabulary was in 2003/4 to initiate a pay review for all civilian staff within the police force. A planned reform, based on a performancerelated pay system, involved a wide-ranging and highly demanding job evaluation of all civilian posts and current pay rates. In a managerial project 'of which many police staff were sceptical of its outcome before it was announced' the end result was a recommendation that involved a reduction in the salaries of hundreds of civilian staff. An unprecedented walkout of civilian staff and public protests outside the force HQ followed the announcement of the results of the pay review.

A series of Inquiries followed this public relations disaster and revealed the profound lack of managerial skill exhibited within the senior management team (Devon and Cornwall Police Authority, 2006). It also laid bare the limited cultural horizons that permeated the police organisation at the highest level. As the Job Evaluation Project, targeted entirely at civilian staff payrates, evolved, it became apparent that financial imperatives 
overshadowed human resource considerations. This did not appear to be a matter of any immediate concern to either the chief officer or senior management team. A report prepared for the Police Authority was to comment:

It appears that there was a lack of interest, involvement and attention from senior management to the project, its progress and particularly, its implications - despite its potential impact on $40 \%$ of the workforce. (Devon and Cornwall Police Authority, 2006: 10)

The same report commented that in the course of the Job Evaluation Project any challenges to or notes of caution about the management of the project, along with potential outcomes, were met with 'at best indifference and at worst with hostility' (Devon and Cornwall Police Authority, 2006: 11). It also found that the project had not been helped by the complete lack of human resources expertise among both ACPO and other senior police personnel (ibid.).

The absence of any expertise held by chief police officers had not acted as any kind of brake on the Project. It does, however, explain the numerous major failings later identified within it by the Police Authority. These failures included, inter alia, an absence of any enquiry as to whether other forces had undertaken similar job evaluation projects and with what result; a failure to seek any external advice or support for the project; a failure to engage with any of the relevant trade unions or staff line-managers; a failure to identify what specialist skills and competencies were necessary to undertake the job evaluation process and the failure to evaluate other potential job evaluation schemes prior to determining the scheme to be adopted (Devon and Cornwall Police Authority, 2006).

Led by a senior police officer who also had to exercise 'day to day responsibility for the South Devon force', the project team lacked any expertise in either the HR field or that of job evaluation. The fact that the scheme related only to civilian staff and not police establishment possibly explains why the absence of any professional skills held by members of the Project Team were not deemed by chief officers to be a matter of concern.

Later claims of impropriety, relating in part to the shredding of documents linked to the Project by members of the Project Team, only served to highlight the degree of suspicion among civilian staff that surrounded the project (Herald Express, 2006). The seizure of all (remaining) documents by an internal police 
investigation team and a subsequent follow-up investigation conducted by the Metropolitan Police did not wholly assuage these apparently justifiable suspicions.

Evidence from the Devon and Cornwall Constabulary case only provides further support for an assessment made some years before on the impact of civilianisation on the police service. In an insightful evaluation of the civilianisation process one senior police officer earlier expressed great concern as to the future management of civilian staff.

Parrett (1998) noted that despite the implementation of the Police and Magistrates' Courts Act in 1994, which passed effective responsibility for all civilian staff from the police (or local) authority to the chief constable, little or nothing had resulted from this significant change in responsibility. Parrett also argued that while the legislation provided an 'important and symbolic' opportunity for chief officers to welcome civilian staff into the police service and also for the police service to 'unequivocally present its vision for the civilianisation process', this opportunity had been entirely missed (Parrett, 1998: 223).

\section{Going for the Big Bang}

It would be wrong to generalise from the Devon and Cornwall experience where bad management, emanating from the senior command team, alienated all staff across the police-civilian divide. Yet the central feature of job evaluation undertaken by that force provides a disturbing insight into the perceptions of civilian staff held even at the most senior level. This does not exactly augur well for the expansion of community support officers. The lack of leadership among police staff in that case may also serve to reinforce a negative stereotype of 'police staff' already prevalent within the police organisational culture. This can be expected also to create a significant barrier to the successful implementation of workforce modernisation and raises fundamental questions as to how this important reform programme can be effectively implemented.

One way forward could be to provide an opportunity for BCU commanders to initiate the reform process by giving them the control of the manpower budget that to date has been denied them. Control of the budget is likely to lead to a substantial increase in police staff numbers as BCU commanders seek to maximise value for money by spending on staffing that is likely to provide the greatest immediate return and long-term benefit. This will inevitably mean a significant expansion of police staff, mixed-economy teams and PCSOs. Evidence to date clearly 
suggests that the latter initiatives have already proved their worth (HMIC, 2004: Appendix J, 84).

As the surveys of BCU commanders show, one of the most critical issues confronting commanders remains that of staffing. Although a range of problems were identified, the most significant was the number of police and civilian staff available to commanders. A further difficulty related to replacing those off sick or seconded to other parts of the force, particularly those seconded to police headquarters. As the Police Superintendents' Survey and report noted:

Aside from ongoing problems of recruitment and retention many respondents felt there was insufficient flexibility to vary the mix of staff particularly between police and civilian staff. Where officers had been given the authority and flexibility to change the mix of staff (they) reported that they had been able to minimise the problems of staff shortages by using specialist staff resources (be they police or civilian) where they would be most effective. This however was closely linked to whether commanders had been delegated both budgets and responsibility for staffing. (Police Superintendents' Association, 2003: 6.2)

It is clear that for BCU commanders, the single most important factor in BCU performance is the availability and competence of both police officers and civilian staff. For a number of commanders one way of addressing staff shortages, particularly among officers, is being able to alter the balance between civilian staff and police officers and this means essentially 'having more civilian staff'. This in turn would allow police officers to focus on 'real police work', which might involve the use of their powers of arrest while civilian staff undertake 'traditional officer tasks like conducting interviews' (Police Superintendents' Association, 2003: 4.2.3).

Ultimately, however, none of this can be entertained in the absence of control by commanders over the budget. While in a number of forces devolved responsibility for budgets has taken place, it remains the case that most of the budget goes on wages and, without control over officer staffing (which generally remains with headquarters), there is little left in the budget to allocate at their own discretion (Police Superintendents' Association, 2003: 4.5). Not surprisingly therefore most commanders registered frustration over the fact that while they were made accountable they could not make budgeting decisions. They were 
in effect made accountable for performance but 'could not control things that affect that performance' (ibid.).

Should the problem of delegated budgets be resolved, this might enable the BCU commander to deal with a number of current problems. These included the high turnover rate of officers, which within inner-city BCUs now invariably means that policing is the responsibility of probationer constables (Police Superintendents' Association, 2003: 4.2.2). Control of the budget would also enable these officers to respond to the problem of staff-shortages, which currently remains the primary characteristic of all BCUs. While staff shortages can be explained in part through unfilled vacancies, sick leave and annual leave, there are a number of commanders who 'express concern over how to handle staff seen as malingering' and who feel that 'the benefits of the pension scheme encouraged some staff to "sit out" their time before retirement' (Police Superintendents' Association, 2003: 4.2.1).

Control of the budget might also enable local commanders to address the perennial problem of the abstraction rate through increased recruitment of police staff. BCU commanders also feel that playing a greater role in budgeting would put commanders in a better position to address local priorities (Police Superintendents' Association, 2003: 4.5). Arguably the identification and response to local need should be the highest priority within a $\mathrm{BCU}$ command and any impediments to realising this objective need to be challenged immediately.

\section{Conclusion}

There are clear advantages to the effective delegation of budgets to BCU level. This should be accompanied with the ending of the Crime Fighting Fund (CFF), which is designed to push up police establishment levels across the country. Effectively used as a means to 'ring-fence' spending on police officers, this government-led initiative now acts as a strait-jacket within police forces as spending can be directed only to police numbers and not to civilian staff. One interesting consequence of this policy has been that currently local commanders are now having to remove operational police from street patrol to take on administrative office-based functions as police civilian staff leave and cannot be replaced. Ironically therefore the CFF is now working to reduce visible patrol strength rather than increase this important function.

Ending the CFF would, along with delegated budgets, allow local BCU commanders for the first time to determine the profile 
of the BCU in ways that would maximise the impact of police resources. This would almost certainly involve a major expansion of specialised civilian staff at BCU level, who would have expertise in a range of IT and other support services. It would also provide a launch-pad for the roll-out of significant modernisation within the service. This would begin to address problems surrounding staff shortages, current abstraction rates and a number of employment practices that are now a matter of concern to local commanders.

Delegated budgets would also encourage the much-needed implementation of Workforce Modernisation. The recruitment of police staff at BCU level would also begin to challenge elements of the police organisational culture that to date have proved so intractable to reform. This has not been achieved in part because at chief officer level there continues to be an indifference (or residual animosity) to civilian personnel. This could yet confound a reform programme that is predicated upon a greatly expanded role for such staff. Research indicates that many BCU commanders would seek to employ many more police staff and fewer police officers, which reflects a perceived need for far greater flexibility to vary the mix of staff particularly between police and civilian staff.

Similarly the much-increased demands on police resources arising from the new Neighbourhood Policing Strategy may also pave the way to major reform. In the absence of a substantial increase in police establishments Neighbourhood Policing Strategy, which is highly manpower-intensive, may be accomplished only through significant increases in police staff linked to an expanded role for both PCSOs and mixed-economy teams.

Recent evidence suggesting that central funding may not match planned manning levels could mean that local authorities may become part-funding bodies for this purpose (Johnston, 2006). This would place greater pressure on police forces and in particular BCU commanders to achieve 'value for money' and therefore act as a further incentive to employ more police staff. Much will ultimately depend on the degree and extent of budget and manpower delegation to BCU commands. At this point, the evidence suggests, it will be at BCU command level where police re-engineering, along with workforce modernisation, is most likely to be implemented successfully. Therefore it will be here that these initiatives can be expected either to succeed or fail and it is at this level that the successful implementation of future police service delivery will be ultimately determined. 


\section{Bibliography}

Bayley, D. (1994) Police for the Future. Oxford: Oxford University Press.

Brain, T. (2006) 'What Price Restructuring Now?' Police Professional April.

Cabinet Office (2003) Leading from the Front Line, The Prime Minister's Office of Public Service Reform. London: Cabinet Office.

Chan, J. (1997) Changing Police Culture. Cambridge: Cambridge University Press.

Devon and Cornwall Police Authority (2006) Review of the Job Evaluation Project. Exeter: Devon and Cornwall Police Authority.

Devon and Cornwall Police Authority (2006) Job Evaluation: Review Instigated by the Police Authority, retrieved at http: //www.depa.police.uk/je_rev/index.htm

Gilbert, T. (2006) Public Support, Police Review 114.

Hellawell, K. (2002) The Outsider. London: Harper Collins.

Herald Express (2006) Cost Query over Police Pay Saga, retrieved from http://wwwanthonysteen.org.uk/record.jsp? $\mathrm{ID}=246 \&$ type $=$ news

HMIC (2004) Appendix J Literature Review for HMIC Thematic Inspection on Civilianisation. London: Home Office.

HMIC (1998) Report on Cleveland Police Force. London: Home Office.

Home Office (2006) 'Police Reform and Protective Services', Letter from Tony McNulty MP, Minister of State, to all Police Chiefs and Chairs of Police Authorities.

Howgrave-Graham, H. M. (1947) Light and Shade at Scotland Yard. London: John Murray.

Johnston, P. (2006) 'Community Police Plans in Jeopardy', Daily Telegraph, ctober.

Loveday, B. (In press a) Comand Units and Local Authorities' International Journal of Police Science and Management.

Loveday, B. (In press b) 'Workforce Modernisation in the Police Service', International Journal of Police Science and Management.

Loveday, B. (2006) Police Reform: Producer-Driven or Consumer-Led? The Police Journal 79 (3): 200-13.

Loveday, B. (1998) Improving the Status of Police Patrol International Journal of Sociology of Law 26.

Loveday, B. and Reid, A. (2003) Going Local: Who Should Run Britain's Police? London: Policy Exchange. 
Mervyn Jones, J. (1980) Organisational Aspects of Police Behaviour. Farnborough: Gower.

Metropolitan Police Service (2006) Interview with OCU Commander Bexley Borough.

O’Byrne, M. (2001) Changing Policing: Revolution not Evolution. Lyme Regis: RHP.

Parrett, L. (1998) Past, Present and Future Roles of Civilian Personnel in the Police Service in England and Wales, $\mathrm{PhD}$ dissertation, University of East Anglia.

PMSU/ Home Office (2004) Police Reform Strategy. London: Prime Minister's Strategy Unit/ Home Office.

Police Professional (2005) 'The £40k Constable', Police Professional 3 June. Aylesbury: Clarity Press.

Police Superintendents' Association (2003) Factors that Impact on BCU Performance Report. London: BRMB Social Research.

Reiner, R. (2000) The Politics of the Police. Oxford: Oxford University Press, 3rd edn.

Souryal, S. (1995) Organisational Structure: Theory into Practice, in The Encyclopedia of Police Science. New York and London: Garland Publishing Inc.

Tazzini, R. (2006) 'Plastic or Pioneering?' Police Professional (August): 26-9. Aylesbury, Herts: Clarity Press. 